\title{
PENENTUAN TINGKAT PENCEMARAN SUNGAI BERDASARKAN KOMPOSISI MAKROBENTOS SEBAGAI BIOINDIKATOR
}

\author{
Rina Budi Satriarti $^{1 *}$, Suci Wulan PaWhestari ${ }^{1}$, MerliYAnA $^{1}$, DAN Nurhaida Widianti ${ }^{1}$ \\ ${ }^{1}$ Program Studi Pendidikan Biologi, Fakultas Tarbiyah dan Keguruan, UIN Raden Intan Lampung, \\ Jalan Endro Suratmin Bandar Lampung \\ *alamat email korespondensi: rinabudisatiyarti@ radenintan.ac.id
}

\begin{tabular}{|c|c|}
\hline Infor & Abstrak/Abstract \\
\hline $\begin{array}{l}\text { Riwayat Naskah : } \\
\text { Diterima pada } 30 \\
\text { November } 2018 \\
\text { Diterima setelah } \\
\text { direvisi pada } 29 \\
\text { Januari } 2019 \\
\text { Diterbitkan pada } 30 \\
\text { Januari } 2019 \\
\text { Kata Kunci: } \\
\text { Pencemaran; } \\
\text { makrobentos; Way } \\
\text { Belau; indeks } \\
\text { keseragaman; indeks } \\
\text { keanekaragaman, } \\
\text { parameter fisika dan } \\
\text { kimia }\end{array}$ & $\begin{array}{l}\text { Hadirnya industri dan kenaikan jumlah penduduk di sekitar sungai Way Belau di Kota Bandar } \\
\text { Lampung menyebabkan pencemaran di aliran sungai. Aktivitas manusia di sepanjang aliran } \\
\text { sungai membuat warna air pada kawasan hilir menjadi kuning pekat. Penelitian ini bertujuan } \\
\text { untuk mengetahui tingkat pencemaran air sungai Way Belau Teluk Betung menggunakan } \\
\text { parameter biologi, fisika, dan kimia. Pengambilan sampel dilakukan dengan teknik Line } \\
\text { Transek pada } 3 \text { titik lokasi penelitian. Hasil penelitian ini menunjukkan bahwa komposisi } \\
\text { makrobentos yang didapat yaitu } 6 \text { famili, diantaranya } 4 \text { famili dari kelas Gastropoda, } 1 \text { famili } \\
\text { dari kelas Crustacea dan } 1 \text { famili dari kelas Polychaeta. Indeks keanekaragaman (H') pada } \\
\text { ketiga lokasi berkisar } 0,562-1,255 \text {. Indeks keseragaman (E) berkisar antara } 0,044-0,287 \text { dan } \\
\text { indeks dominansi (D) berkisar antara } 0,313-0,625 \text {. Hasil pengukuran parameter fisika-kimia } \\
\text { pada ketiga lokasi yaitu suhu berkisar } 22^{\circ} \mathrm{C}-26^{\circ} \mathrm{C} \text {, pH berkisar } 5-7 \text {, kecerahan berkisar } 19-40 \\
\text { cm, DO berkisar } 5-7 \mathrm{mg} / \mathrm{L} \text {, BOD berkisar } 1-5 \mathrm{mg} / \mathrm{L} \text {, COD berkisar } 1-2 \mathrm{mg} / \mathrm{L} \text {. Berdasarkan } \\
\text { data diatas menjukkan bahwa kualitas perairan tercemar sedang. }\end{array}$ \\
\hline $\begin{array}{l}\text { Keywords: } \\
\text { Pollution, } \\
\text { macrobentos, Way } \\
\text { Belau, uniformity } \\
\text { index, diversity } \\
\text { index, physic and } \\
\text { chemical parameters. }\end{array}$ & $\begin{array}{l}\text { Industry and high population across Way Belau river at Bandar Lampung cause river } \\
\text { pollution. Human activities made the colour of the river turn to yellow. This research was } \\
\text { conducted to predict water pollution level in Way Belau, Teluk Betung by analyzing results } \\
\text { from biological, physical, and chemical parameters. Samples was taken by Line Transcet } \\
\text { technique at three points. The result of this result shows that there are six families of } \\
\text { macrobentos. Among them, four families from Gastrophode class, one family from Crustacea, } \\
\text { and one family from Polychaeta family. Diversity index }\left(H^{\prime}\right) \text { from three locations was at } \\
\text { range } 0,562-1,255 \text {. Uniformity index }(E) \text { was } 0,313-0,625 \text {. Physic and chemical parameters } \\
\text { measurement shows that the average temperature was } 22^{\circ} \mathrm{C}-26^{\circ} \mathrm{C}, \mathrm{pH} \text { was } 5-7 \text {, visibility } 19- \\
40 \mathrm{~cm}, \mathrm{DO} \text { was } 5-7 \mathrm{mg} / \mathrm{L}, \mathrm{BOD} 1-5 \mathrm{mg} / \mathrm{L} \text {, and } C O D \mathrm{D} 1,2 \mathrm{mg} / \mathrm{L} \text {. Based on data we predict the } \\
\text { quality of Way Belau river was moderately polluted. }\end{array}$ \\
\hline
\end{tabular}

\section{PENDAHULUAN}

Air adalah bagian dari sumber daya alam utama bagi kelangsungan hidup seluruh organisme [1]. Manusia memanfaatkan air untuk kehidupan sehari-hari, irigasi, industri, perikanan, pembangkit tenaga listrik, dan rekreasi [2]. Semua jenis aktivitas manusia dari kebutuhan pangan sampai kebutuhan industri memerlukan air dengan jumlah yang dan kualitas yang sesuai dengan kebutuhannya.

Kebutuhan air tergantung pada kuantitas dan kualitasnya. Seiring dengan perkembangan ilmu pengetahuan, teknologi, dan meningkatnya jumlah penduduk, maka kebutuhan air pun akan meningkat [2]. Sementara itu luas hutan yang berfungsi sebagai tempat penyimpanan air tanah terus berkurang, karena dikonversi menjadi lahan pertanian, tempat pemukiman penduduk, kawasan industri, dan tempat kegiatan lainnya. Salah satu ekosistem air tawar yang menyediakan air adalah sungai. Sungai biasanya digunakan sebagai untuk memenuhi kebutuhan hidup sehari-hari. Sungai dapat mengalami gangguan keseimbangan ekosistem, biasanya karena ulah manusia yang menghasilkan bahan pencemar bagi sungai.

Sungai merupakan salah satu penyedia air yang paling utama bagi manusia. Dengan demikian, pencemaran pada air sungai akan berdampak negatif bagi lingkungan sekitarnya. Pencemaran pada sungai Way Belau telah merubah warna air pada daerah hilir menjadi kuning pekat, sehingga kualitas sungai menurun.

Pada perairan terdapat dua kelompok organisme, yang toleran dan tidak toleran terhadap bahan pencemar. Organisme yang toleran dapat 
dijadikan sebagai indikator biologi pada perairan tercemar. Organisme yang tidak toleran akan mengalami penurunan kelimpahannya, bahkan akan hilang dari lingkungan perairan tersebut. Organisme yang tidak toleran dapat dijadikan indikator terhadap kualitas air yang bersih dan normal [3].

Reaksi organisme sebagai indikator pencemaran berguna pada penentuan kualitas perairan. Makrobentos adalah salah satu organisme akuatik menetap di dasar perairan yang memiliki pergerakan relatif lambat serta daur hidup yang relatif lama. Sehingga, makrobentos memiliki kemampuan untuk merespon kondisi kualitas air secara terus menerus. Makrobentos biasanya berupa siput, kepiting, tiram air tawar, kerang, dan termasuk larva serangga [4].

\section{EKSPERIMEN}

\section{Material dan Instrumentasi}

Alat yang digunakan dalam penelitian ini meliputi, saringan dengan mata saring $0,5 \mathrm{~mm}$ atau $1 \mathrm{~mm}, \mathrm{pH}$ meter, DO meter, Termometer air raksa skala $0^{\circ} \mathrm{C}-100^{\circ} \mathrm{C}$, mistar berskala $1 \mathrm{~cm}$, sekop, hand corer, toples, mikroskop atau lup, alat tulis, kamera (Nikon), kertas label, dan paralon dengan diameter $10 \mathrm{~cm}$. Bahan yang digunakan dalam penelitian ini adalah formalin (Merck) 4\%, etanol (Merck) $70 \%$ dan akuades.

\section{Prosedur}

\section{Penentuan Titik Lokasi}

Penelitian ini menggunakan 3 stasiun pengambilan sampel, masing-masing stasiun terdapat 3 titik pengambilam sampel sehingga berjumlah 9 titik lokasi. Stasiun dalam pengambilan sampel dilakukan dengan pembuatan peta topografi pada saat observasi serta penentuan letak garis-garis transek (metode line intercept $=$ line transek).

\section{Pengambilan Sampel}

Pengambilan sampel makrobentos dilakukan pada pagi hari di sungai Way Belau Teluk Betung dengan menggunakan hand corer. Sampel yang sudah didapat kemudian dimasukkan kedalam toples diberi formalin $4 \%$ dan di bawa ke laboratorium untuk dilakukan penyucian. Penyucian dilakukan dengan cara meletakkan sampel di atas saringan, kemudian sampel disiram dengan air mengalir sambil diayak untuk menghilangkan partikel yang berupa pasir. Sampel yang tertinggal di atas saringan adalah makrobentos. Setelah dilakukan penyaringan maka makrobentos diawetkan dengan etanol $70 \%$. Setelah itu sampel dilakukan pengamatan di bawah mikroskop untuk di identifikasi dengan menggunakan acuan buku yang berjudul Guide to the Freshwater Aquatic Microdrile Oligochaetes of North America [5]. Pengukuran parameter fisika yaitu suhu dan kecerahan dilakukan langsung dilapangan. Untuk pengukuran parameter kimia yaitu $\mathrm{pH}$ dilakukan secara langsung, sedangkan COD, BOD dan DO diukur di laboratorium.

\section{Analisis Data}

\section{Indeks Keanekaragaman ( $H^{\prime}$ ) Shannon-Wiener}

Indeks ini digunakan untuk mengetahui keanekaragaman jenis biota perairan, dengan rumus sebagai berikut:Adsorben ini dibuat dari serbuk tempurung kelapa instrumen AAS [7].

$$
\mathrm{H}^{\prime}=\sum_{l=1}^{s} P i(\text { In Pi })
$$

Keterangan:

$$
\begin{array}{ll}
\mathrm{H}^{\prime} & =\text { Indeks Keanekaragaman } \\
\mathrm{Pi} & =\text { ni/N } \\
\mathrm{ni} & =\text { jumlah individu spesies ke-i } \\
\mathrm{N} & =\text { jumlah individu seluruh spesies } \\
\mathrm{S} & =\text { jumlah spesies }
\end{array}
$$

\section{Indeks Keanekaragaman Jenis Shannon-Wiener}

$$
\begin{array}{ll}
>2,0 & =\text { Tidak tercemar } \\
2,0-1,5 & =\text { Tercemar ringan } \\
1,5-1,0 & =\text { Tercemar sedang } \\
<1,0 & =\text { Tercemar berat }
\end{array}
$$

\section{Indeks keseragaman (E) Shannon-Wiener}

Keseragaman yaitu komposisi jumlah individu dalam setiap genus yang terdapat dalam setiap genus yang terdapat dalam komunitas [6].

$\mathrm{E}=\frac{\mathrm{H}^{\prime}}{\mathrm{H} \text { maks }}$

Keterangan:

$$
\begin{array}{ll}
\mathrm{E} & =\text { Indeks keseragaman } \\
\mathrm{H} & =\text { Indeks keanekaragaman } \\
\mathrm{H} \text { maks } & =\text { indeks keanekaragaman spesies } \\
& \text { maksimum }
\end{array}
$$

Nilai keseragaman (E) suatu populasi dengan kisaran antara 0-1 dengan kategori:

$$
\begin{array}{ll}
\mathrm{E}>0,6 & =\text { keseragaman tinggi } \\
0,4<\mathrm{E}<0,6 & =\text { keseragaman sedang } \\
\mathrm{E}<0,4 & =\text { keseragaman rendah }
\end{array}
$$




\section{Indeks dominansi (D) Simpson}

Untuk menghitung dominansi makrobentos maka digunakan indeks dominansi dari Simpson [7].

$\mathrm{D}=\frac{\mathrm{ni}}{\mathrm{N}} \times 100 \%$

Keterangan :

$\mathrm{D} \quad=$ Indeks Dominansi

ni $\quad=$ Jumlah individu jenis

$\mathrm{N} \quad=$ Jumlah total individu

Kategori:

$00,0<\mathrm{D} \leq 0,30=$ Dominansi rendah

$0,30<\mathrm{D} \leq 0,60=$ Dominansi sedang

$0,60<\mathrm{D} \leq 1,00=$ Dominansi tinggi

\section{HASIL DAN PEMBAHASAN}

\section{Parameter Biologi}

Berdasarkan penelitian yang telah dilakukan telah diperoleh beberapa jenis makrobentos yang setiap titik lokasi terdiri dari beberapa famili. Dalam penelitian tersebut pengambilan sampel dilakukan sebanyak 2 kali. Untuk pengambilan sampel pertama dan kedua diperoleh beberapa famili seperti yang disajikan pada Tabel 1 .

Tabel 1. Komposisi hewan makrobentos di sungai Way Belau Teluk Betung

\begin{tabular}{crccc}
\hline \multirow{2}{*}{ No } & \multirow{2}{*}{ Famili } & \multicolumn{3}{c}{ Jumlah hewan (individu) } \\
\cline { 3 - 5 } & & Stasiun & Stasiun & Stasiun \\
& & 1 & 2 & 3 \\
\hline 1 & Ampularidae & 4 & 12 & 11 \\
2 & Thiaridae & 6 & 3 & 10 \\
3 & Pleuroceridae & 3 & 0 & 0 \\
4 & Bulimidae & 0 & 0 & 2 \\
5 & Pisionidae & 1 & 1 & 1 \\
6 & Cancridae & 0 & 0 & 1 \\
& Jumlah total & 14 & 16 & 25 \\
\hline
\end{tabular}

Keanekaragaman hayati adalah indikator kestabilan suatu ekosistem. Jika keanekaragaman semakin tinggi dalam suatu habitat atau semakin banyak populasi penyusun suatu komunitas, maka ekosistem akan menjadi lebih stabil. Komunitas makrobentos secara keseluruhan pada sungai Way Belau terdapat 3 kelas dan 6 famili. Kelas Gastropoda terdapat 4 famili yaitu Bulimidae, Pleuroceridae, Thiaridae, dan Ampularidae. Sedangkan pada kelas Crustacea terdapat 1 famili yaitu Cancridae dan kelas Pholychaeta terdapat 1 famili yaitu Pisionidae. Dari pengamatan tersebut, dapat di jelaskan bahwa telah ada satu famili makrobentos yang mulai mendominasi jenis makrobentos di Way
Belau. Jika terdapat dominasi makrobentos pada suatu perairan, dapat diperkirakan bahwa kualitas perairan tersebut telah menurun.

Kelompok dari kelas Gastropoda pada setiap stasiun lebih banyak ditemukan dibandingkan dengan jumlah kelas Crustacea dan Polychaeta. Gastropoda ini banyak ditemukan karena hewan ini dapat bertahan hidup pada kondisi perairan tercemar berat karena tubuhnya mempunyai operkulum yang dapat digunakan untuk menutup cangkangnya pada saat kondisi perairan berada di luar kisaran toleransinya. Komposisi makrobentos pada sampel pertama lebih sedikit dibandingkan sampel kedua, hal ini disebabkan pada substrat daerah penelitian sebagian besar adalah berbatu dan berlumpur. Pada saat penelitian pertama juga dilakukan ketika musim hujan, dimana arus sungainya menjadi deras dan air berubah warna menjadi keruh. Berdasarkan cuaca tersebut maka dalam pengambilan sampel makrobentosnya menjadi susah untuk diambil oleh karena itu sampel pertama lebih sedikit dibandingkan dengan sampel kedua.

Kelompok dari kelas Gastropoda pada setiap stasiun lebih banyak ditemukan dibandingkan dengan jumlah kelas Crustacea dan Polychaeta. Gastropoda ini banyak ditemukan karena hewan ini dapat bertahan hidup pada kondisi perairan tercemar berat karena tubuhnya mempunyai operkulum yang dapat digunakan untuk menutup cangkangnya pada saat kondisi perairan berada di luar kisaran toleransinya. Komposisi makrobentos pada sampel pertama lebih sedikit dibandingkan sampel kedua, hal ini disebabkan pada substrat daerah penelitian sebagian besar adalah berbatu dan berlumpur. Pada saat penelitian pertama juga dilakukan ketika musim hujan, dimana arus sungainya menjadi deras dan air berubah warna menjadi keruh. Berdasarkan cuaca tersebut maka dalam pengambilan sampel makrobentosnya menjadi susah untuk diambil oleh karena itu sampel pertama lebih sedikit dibandingkan dengan sampel kedua.

Hasil dari penelitian dengan identifikasi dan perhitungan jumlah populasi masing-masing individu pada 3 stasiun penelitian, dilanjutkan dengan analisis Indeks Keanekaragaman (H'), Indeks Keseragaman (E), Indeks Dominansi (D) yang disajikan pada Tabel 2. 
Tabel 2. Indeks Keanekaragaman, Keseragaman, dan Dominansi di Sungai Way Belau Teluk Betung

\begin{tabular}{|c|c|c|c|c|c|}
\hline \multirow{2}{*}{ No } & \multirow{2}{*}{ Indeks } & \multicolumn{3}{|c|}{ Stasiun } & Kategori \\
\hline & & 1 & 2 & 3 & \\
\hline 1 & $\begin{array}{l}\text { Keanekaraga } \\
\text { man } \\
\text { Shannon- } \\
\text { Wiener }\end{array}$ & 1,255 & 0,703 & 1,233 & $\begin{array}{l}>2,0= \\
\text { Tidak } \\
\text { tercemar } \\
2,0-1,5= \\
\text { Tercemar } \\
\text { ringan } \\
1,5-1,0= \\
\text { Tercemar } \\
\text { sedang } \\
<1,0 \\
\text { Tercemar } \\
\text { berat }\end{array}$ \\
\hline 2 & $\begin{array}{l}\text { Dominansi } \\
\text { Simpson }\end{array}$ & 0,313 & 0,602 & 0,351 & $\begin{array}{l}00,0-0,30= \\
\text { Rendah } \\
0,30-0,60= \\
\text { Sedang } \\
0,60-1,00= \\
\text { Tinggi }\end{array}$ \\
\hline 3 & $\begin{array}{l}\text { Keseragaman } \\
\text { Shannon- } \\
\text { Wiener }\end{array}$ & 0,157 & 0,044 & 0,059 & $\begin{array}{l}>0,6= \\
\text { Tinggi } \\
0,6-0,4= \\
\text { Sedang } \\
<0,4 \\
\text { Rendah }\end{array}$ \\
\hline
\end{tabular}

\section{Parameter Fisika dan Kimia}

Secara umum parameter fisika dan kimia di dalam suatu perairan menjadi faktor penentu atau pengendali bagi kehidupan organisme yang ada di dalam sungai Way Belau Teluk Betung. Parameter fisika yang diukur pada penelitian ini adalah suhu dan kecerahan. Sedangkan untuk parameter kimia yang diukur adalah $\mathrm{pH}, \mathrm{DO}, \mathrm{BOD}$, dan COD.

Suhu memiliki peranan penting dalam mengendalikan ekosistem perairan. Secara umum laju pertumbuhan meningkat sejalan dengan kenaikan suhu. Dampak yang terjadi akibat peningkatan suhu berupa penurunan jumlah oksigen terlarut, peningkatan reaksi kimia, maka akan berkurangnya aktivitas kehidupan organisme perairan tersebut. Suhu pada ketiga stasiun berkisar antara $22,3^{\circ} \mathrm{C}-26,8^{\circ} \mathrm{C}$. Suhu yang paling rendah terdapat pada stasiun 2 yaitu $22,3^{\circ} \mathrm{C}$. Suhu yang baik bagi organisme untuk berkembang adalah suhu yang berkisar antara $23^{\circ} \mathrm{C}-35^{\circ} \mathrm{C}$ bahwa nilai suhu tersebut masih menunjang kehidupan organisme perairan.

Perairan dengan $\mathrm{pH}$ tinggi ataupun rendah akan mempengaruhi ketahanan hidup organisme yang hidup didalamnya baik bersifat asam ataupun basa. Berdasarkan hasil penelitian sampel pertama dan kedua $\mathrm{pH}$ yang diperoleh berkisar antara 5-7, rendahnya jumlah jenis pada stasiun 2 berhubungan dengan sedikitnya vegetasi di daratan sekitar perairan dan $\mathrm{pH}$ substrat yang bersifat asam. Keasaman $\mathrm{pH}$ pada stasiun 2 disebabkan karena terdapat sampah-sampah yang tertahan di badan sungai maka terjadi pembusukan. Proses pembusukan sampah dapat terjadi secara aerob maupun anaerob. Proses aerob terjadi di daerah air sedangkan anaerob terjadi di daerah endapan lumpur di dasar sungai. Proses dari anaerob ini tidak merupakan peristiwa yang berdiri sendiri tetapi diikuti oleh siklus karbon, siklus nitrogen dan siklus oksigen.

Perairan dengan $\mathrm{pH}$ tinggi ataupun rendah akan mempengaruhi ketahanan hidup organisme yang hidup didalamnya baik bersifat asam ataupun basa. Berdasarkan hasil penelitian sampel pertama dan kedua $\mathrm{pH}$ yang diperoleh berkisar antara 5-7, rendahnya jumlah jenis pada stasiun 2 berhubungan dengan sedikitnya vegetasi di daratan sekitar perairan dan $\mathrm{pH}$ substrat yang bersifat asam. keasaman $\mathrm{pH}$ pada stasiun 2 disebabkan karena terdapat sampah-sampah yang tertahan di badan sungai maka terjadi pembusukan. Proses pembusukan sampah dapat terjadi secara aerob maupun anaerob. Proses aerob terjadi di daerah air sedangkan anaerob terjadi di daerah endapan lumpur di dasar sungai. Proses dari anaerob ini tidak merupakan peristiwa yang berdiri sendiri tetapi diikuti oleh siklus karbon, siklus nitrogen dan siklus oksigen.

Tabel 3. Hasil pengukuran parameter fisika dan kimia di Sungai Way Belau Teluk Betung

\begin{tabular}{|c|c|c|c|c|}
\hline \multirow[b]{2}{*}{ No } & \multirow[b]{2}{*}{ Parameter } & \multicolumn{2}{|c|}{ Pengambilan Sampel } & \multirow[b]{2}{*}{$\begin{array}{l}\text { Baku } \\
\text { Mutu }\end{array}$} \\
\hline & & $\begin{array}{l}\text { Sampel } \\
\text { pertama }\end{array}$ & $\begin{array}{c}\text { Sampel } \\
\text { kedua }\end{array}$ & \\
\hline 1 & Suhu & $\begin{array}{l}26,5^{\circ} \mathrm{C}- \\
26,8^{\circ} \mathrm{C}\end{array}$ & $\begin{array}{l}22,3^{\circ} \mathrm{C}- \\
25,3^{\circ} \mathrm{C}\end{array}$ & $38^{\circ} \mathrm{C}$ \\
\hline 2 & Kecerahan & $\begin{array}{l}24 \mathrm{~cm}- \\
40,6 \mathrm{~cm}\end{array}$ & $\begin{array}{l}19,6 \mathrm{~cm}- \\
34 \mathrm{~cm}\end{array}$ & $10 \mathrm{~cm}$ \\
\hline 3 & $\mathrm{pH}$ & $5,6-7,3$ & $5-6$ & $7-8,5$ \\
\hline 4 & DO & $\begin{array}{l}5,6 \mathrm{mg} / \mathrm{L}- \\
7,3 \mathrm{mg} / \mathrm{L}\end{array}$ & $\begin{array}{l}5,6 \\
\mathrm{mg} / \mathrm{L}-7,3 \\
\mathrm{mg} / \mathrm{L}\end{array}$ & $>5 \mathrm{mg} / \mathrm{L}$ \\
\hline 5 & BOD & $\begin{array}{l}1,6 \mathrm{mg} / \mathrm{L}- \\
3 \mathrm{mg} / \mathrm{L}\end{array}$ & $\begin{array}{l}3,3 \\
\mathrm{mg} / \mathrm{L}-5 \\
\mathrm{mg} / \mathrm{L}\end{array}$ & $10 \mathrm{mg} / \mathrm{L}$ \\
\hline 6 & COD & $\begin{array}{l}1,3 \mathrm{mg} / \mathrm{L}- \\
2 \mathrm{mg} / \mathrm{L}\end{array}$ & $2 \mathrm{mg} / \mathrm{L}$ & $\begin{array}{l}100 \\
\mathrm{mg} / \mathrm{L}\end{array}$ \\
\hline
\end{tabular}

DO (Dissolved Oxygen), Sumber utama oksigen dalam suatu perairan berasal dari suatu proses difusi dari udara bebas dan hasil fotosintesis organisme yang hidup dalam perairan. Oksigen terlarut (DO) pada ketiiga stasiun berkisar $5,6 \mathrm{mg} / \mathrm{L}-7,3 \mathrm{mg} / \mathrm{L}$. DO tertinggi pada stasiun 3 sebesar $7,3 \mathrm{mg} / \mathrm{L}$ dan stasiun terendah pada stasiun 1 sebesar 5,6 mg/L. Tingginya DO pada stasiun 3 berkaitan dengan rendahnya suhu perairan tersebut. Suhu mempunyai pengaruh besar terhadap kelarutan oksigen, jika suhu naik 
maka oksigen didalam air akan menurun. Selain suhu, jenis sedimen pada suatu perairan juga berpengaruh pada tingginya DO. Pada stasiun 3 tersebut sedimennya berpasir karena pada sedimen berpasir kandungan oksigen relatif besar dibandingkan sedimen yang halus[10].

COD (Chemical Oxygen Demand) adalah Jumlah oksigen yang diperlukan untuk mengoksidasi bahan kimia diperairan dengan menggunakan oksidator kuat. Oksidator kuat berupa kalium bikromat yang ditambah asam pekat dengan katalisator perak sulfat. Penggunaan kedua bahan ini akan membuat segala macam bahan organik baik yang mudah terurai maupun yang kompleks dan sulit terurai akan teroksidasi. Besar kecilnya nilai COD memiliki dampak yang sama terhadap makrobentos seperti BOD. Hal tersebut dikarenakan keduanya merupakan perhitungan banyaknya oksigen (DO) yang digunakan untuk menguraikan bahan organik. Nilai COD pada ketiga lokasi berkisar antara $1,3 \mathrm{mg} / \mathrm{L}-2 \mathrm{mg} / \mathrm{L}$. COD yang terendah terdapat pada stasiun 3 sampel pertama yaitu $1,3 \mathrm{mg} / \mathrm{L}$. Sedangkan pada stasiun 1 dan 2 sampel pertama yaitu $2 \mathrm{mg} / \mathrm{L}$. Untuk sampel kedua pada stasiun 1,2 dan 3 juga didapatkan nilai yang sama yaitu 2 $\mathrm{mg} / \mathrm{L}$. Nilai COD hasil penelitian yang telah dilakukan termasuk kedalam kategori rendah karena menurut standar baku mutu air berdasarkan peraturan KLH No. 5 Tahun 2014, menjelaskan bahwa standar COD suatu perairan yaitu 100 $\mathrm{mg} / \mathrm{L}$. Berdasarkan peraturan tersebut bahwa pada semua stasiun penelitian oksigen yang diperlukan untuk mengurai seluruh bahan organik yang terkandung dalam air hanya sedikit.

BOD (Biologycal Oxygen Demand), dapat dinyatakan sebagai banyaknya oksigen yang digunakan mikroorganisme dalam penguraian bahan organik. Semakin tinggi nilai BOD semakin besar bahan organik yang ada di perairan tersebut karena banyaknya bahan organik maupun anorganik yang terlarut dapat mempengaruhi kemampuan organisme untuk mengurai zat-zat tersebut akan semakin rendah. Pada penelitian ini rentang BOD pada pengambilan pertama 1,6-3 $\mathrm{mg} / \mathrm{L}$ dan pengambilan kedua 3,3-5 $\mathrm{mg} / \mathrm{L}$. Dapat dilihat rentang BOD masih dalam standar bakumutu perairan.

\section{SIMPULAN}

Dari analisis data yang dilakukan, maka dapat disimpulkan bahwa pengujian dengan penggunaan parameter biologi, fisika, dan kimia. Sungai Way belau tergolong pada kategori tercema level sedang. Ditinjau dari keanekaragaman, tingkat keaneka ragaman makrobentos pada sungai termasuk pada kategori rendah.

\section{REFERENSI}

[1] Soegianto and Agoes, Ekologi Perairan Tawar. Surabaya: Pusat Penerbitan dan Percetakan (AUP), 2010.

[2] Murtianingtyas and Eki, "Identifikasi Invertebrata Makro Sebagai Bioindikator Kualitas Air Sungai Ranu Pakis di Kecamatan Klakah Kabupaten Lumajang," Universitas Jember, Skripsi 2006.

[3] Melati and Ferianita Fachrul, Metode Sampling Bioekologi. Jakarta: Bumi Aksara, 2007.

[4] Boen and S Oemarjati, Taksonomi Avertebrata. Jakarta: Universitas Indonesia, 1990.

[5] R O Brinkhurst, "Guide to the Freshwater Aquatic Microdrile Oligochaetes of North America Canadian Special," Publie pier, 1986.

[6] C J Krebs, Ecological Methodology. New York: Harper and Row, 1989.

[7] E P Odum, Dasar-dasar Ekologi. Yogyakarta: Gajahmada University Press, 1993. 